\title{
SPATIAL RESEARCH STUDY OF PERUVIAN IMMIGRANTS IN SANTIAGO DE CHILE
}

\section{PROSTORSKA RAZISKAVA PERUJSKIH PRISELJENCEV V SANTIAGU}

Aloisia Gomez Segovia

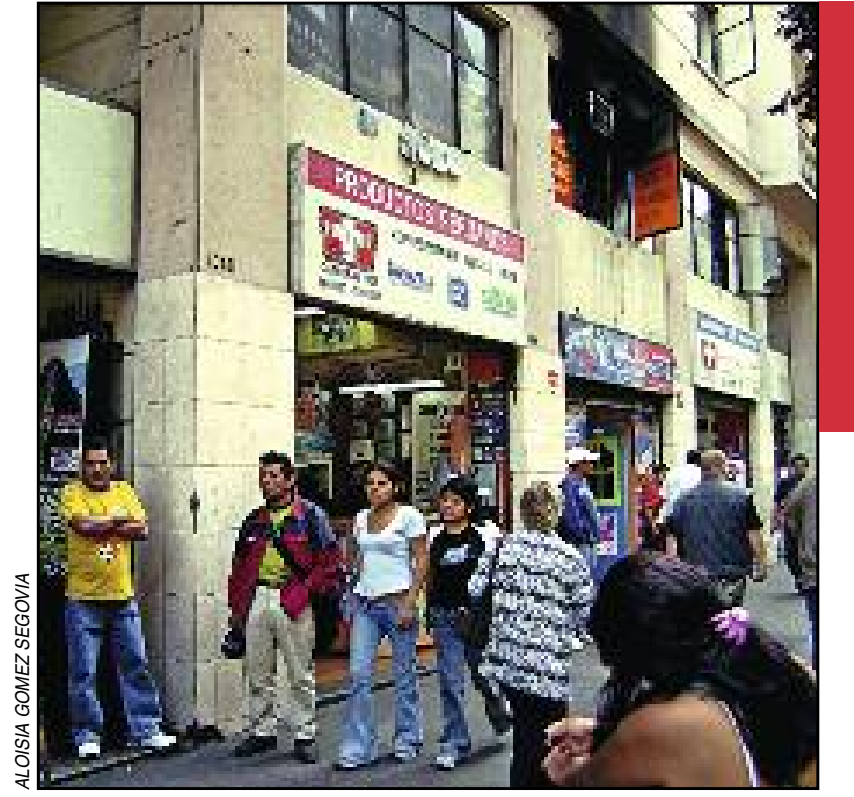

Peruvian products at the Catedral street in the centre of Santiago. Perujski proizvodi na ulici Catedral v centru Santiaga. 


\section{Spatial research study of Peruvian immigrants in Santiago de Chile}

DOI: $10.3986 /$ AGS51109

UDC: 911.3:314.151.3-054.72(83)

COBISS: 1.01

ABSTRACT: The article offers results of the social-spatial research study of Peruvian immigrants in the Chilean capital of Santiago de Chile. The permanent Peruvian immigration to Santiago started at the beginning of the 1990s, and has been quickly rising since 1995. Peruvians are, next to Argentineans, the second largest group of immigrants in Chile, while in the urban area of Santiago they are even the largest immigrant group. The concentration of Peruvian immigrants in the old city centre is clearly visible, what raised the attention of the Chilean society, media and scientists. With the help of demographic data from 2002 we want to show the structure of Peruvian immigrants and visualize their spatial distribution by maps.

KEY WORDS: geography, immigrations, Peruvian immigrants, demographic structure, international immigration, Santiago de Chile

The article was submitted for publication on October 18, 2010.

ADDRESS:

Aloisia Gomez Segovia, M. Sc.

Dornach 18, A - 9162 Strau, Austria

E-mail: aloisiagomez@gmail.com

\section{Contents}

1 Introduction

2 The area of spatial research study of Peruvian immigrants

3 Cartographic illustration of spatial research study on different levels

4 The structure of Peruvian immigrants in Santiago (Chile) 198

5 Conclusion 202

6 Literature 202 


\section{Introduction}

The international permanent immigration of Peruvians to the neighbouring country of Chile started around 1990. In the same year, the Peruvian economy was, under the leadership of the Peruvian president, Alan Gracian, affected by an extreme recession, which resulted in immense hyperinflation of reaching $7000 \%$. All these factors contributed to high levels of unemployment and extreme poverty. In the same year, the government was taken over by Alberto Fujimori, who in 1992, with coup d'état, established dictatorship.

The 1990 also marked the end of the 17-years long dictatorship in Chile, as democracy was re-established, which led to the political stabilization of the country.

From 1973 onwards, when Augusto Pinochet overthrew the country's government against the socialist government of Salvador Allende and violently established dictatorship, Chile saw the start of a controlled restructuring of the economy. The new economy politics was based on the premises of the Chicago school and the multilateral organizations, such as the World Bank and the International Monetary Fund (Luque Brazan 2007). The new capitalist economic system influenced mainly the urban, political, economic and social centres, the capital Santiago de Chile. This resulted in the de-regulation of the land market and in the expansion, and even in some cases, the abolition of city borders. Inhabitants with a higher social status started to move from the old city centre to the outskirts of the city in light of striving towards a better quality of living, where they were not anymore exposed to the air and sound pollutions (Janoschka and Borsdorf 2005 and Hidalgo, Borsdorf and Zunino 2008). The suburbanization phase started. Built-up areas of Santiago expanded for 10.000 hectares over the 15-year period between 1990 and 1995 (Ducci 1998). According to the model of city development of Latin-American cities (Borsdorf, Bähr and Janoschka 2002) the fourth and still current phase of reconstruction started in the 1970s. Its characteristic is the fragmentation of the compact city centre into a multi-core city, which spreads itself as an oil stain (Ducci 1998 and Borsdorf 2003). The city development of Santiago shows the consistency of neo-liberal economic transformation with numerous privatizations and the loss of the role of state government in the competitive market economy. The expansion of the city centre resulted in the migrations of the population from the old city centre of Santiago, which brought many vacant areas of city centre with lower property prices for Peruvian immigrants.

The first Peruvian immigrants at the start of the 1990s were mostly political refugees. When democracy was reestablished in Chile, the capital Santiago de Chile saw the establishment of the United Nations High Commission for Political Refugees (ACNUR), mainly due to more than half a million Chilean political refugees in exile, who started to return to their homeland. The Chilean government and the organization were on the legal and institutional levels not ready to accept political refugees from Peru (Luque Brazan 2007).

From 1995 onwards the percentage of Peruvian immigrants has quickly risen. This also represented the start of the »new Peruvian immigration « of urban type, of lower social classes and mainly of workforce (Martinez 2003; Stefoni 2007a). For the Argentines the Peruvians represent the second largest group of immigrants in Chile, while in the urban region of Santiago de Chile they are even the largest immigrant group. Between 1992 and 2002 the Peruvian immigration in Chile rose for more than $350 \%$. In the same period the number of Argentinean immigrants rose for only 45\%. Till 2002 more than $80 \%$ of all Peruvian immigrants in Chile moved to the capital Santiago (Huatay and Jimenez 2003).

The attention of the Chilean society has focused on the Peruvian minority since the 1990s. The Chilean newspapers started to write about »the waves of Peruvian immigrants «, as though the statistical data show that the Peruvian immigrants to Chile represented only $0.36 \%$ of the entire population in 2002 . Compared to other traditional countries of immigrations, this percentage is rather low, but on the other hand it is interesting that the Peruvian minority has expanded greatly recently.

This article aims to show the spatial distribution of Peruvian immigrants in the urban centre of Santiago and represent their structure by demographic data, including the age, employment, social and gender struture.

For the purposes of this research the statistical data was acquired from the National Statistical Institute of Chile (Instituto Nacional de Estadistica - INE), which publishes a new population registry every ten years. In the current research of Peruvian immigrants the data from the latest population registry from 2002 were employed, but it should be pointed out that the data does not include any non-registered immigrants. Quite possibly these non-registered Peruvian immigrants represent an important percentage in Santiago, 
while their number can only be regarded as an estimation. The immigration data is hard to process, as it is only based on acquiring data about people moving and/or migrating. The population registers from 2002 included 38.000 Peruvian immigrants in Chile, while the Foreign Ministry of Peru estimates that the actual number of Peruvian immigrants in 2003 was more than 81.000 immigrants. The new research studies of the Statistical Institute of Peru (INEI), the International Organization for Migrations (IOM) and the Peruvian Migration Institution (DIGEMIN) show that more than 180.000 Peruvians moved to Chile for at least 6 months between 1990 and 2007. In 2007 the Chilean government passed the Act of Amnesty, with which more than 15.000 non-registered Peruvian immigrants took advantage of acquiring their permits for living in Chile.

Taking all the aforementioned factors into account, we can assume that the share of non-registered Peruvian immigrants in Santiago is of great importance, although they were not part of our spatial and demographic research, due to the lack of data.

\section{The areas included in the spatial research study of Peruvian immigrants}

The research area was divided onto three levels (Figure 1). The first level is represented by the metropolitan area of Santiago which covers the urban parts and comprises 34 municipalities. Some municipalities on the outskirts are only partly included in the urban region of Santiago. This area is known also as »el gran Santiago « - the Great Santiago. On the second level we determined the area of twelve central municipalities of Santiago. We assumed that the Peruvian immigrants are mostly located in the centre of the city. The third level is represented by two chosen municipalities. As first we determined the central munic-

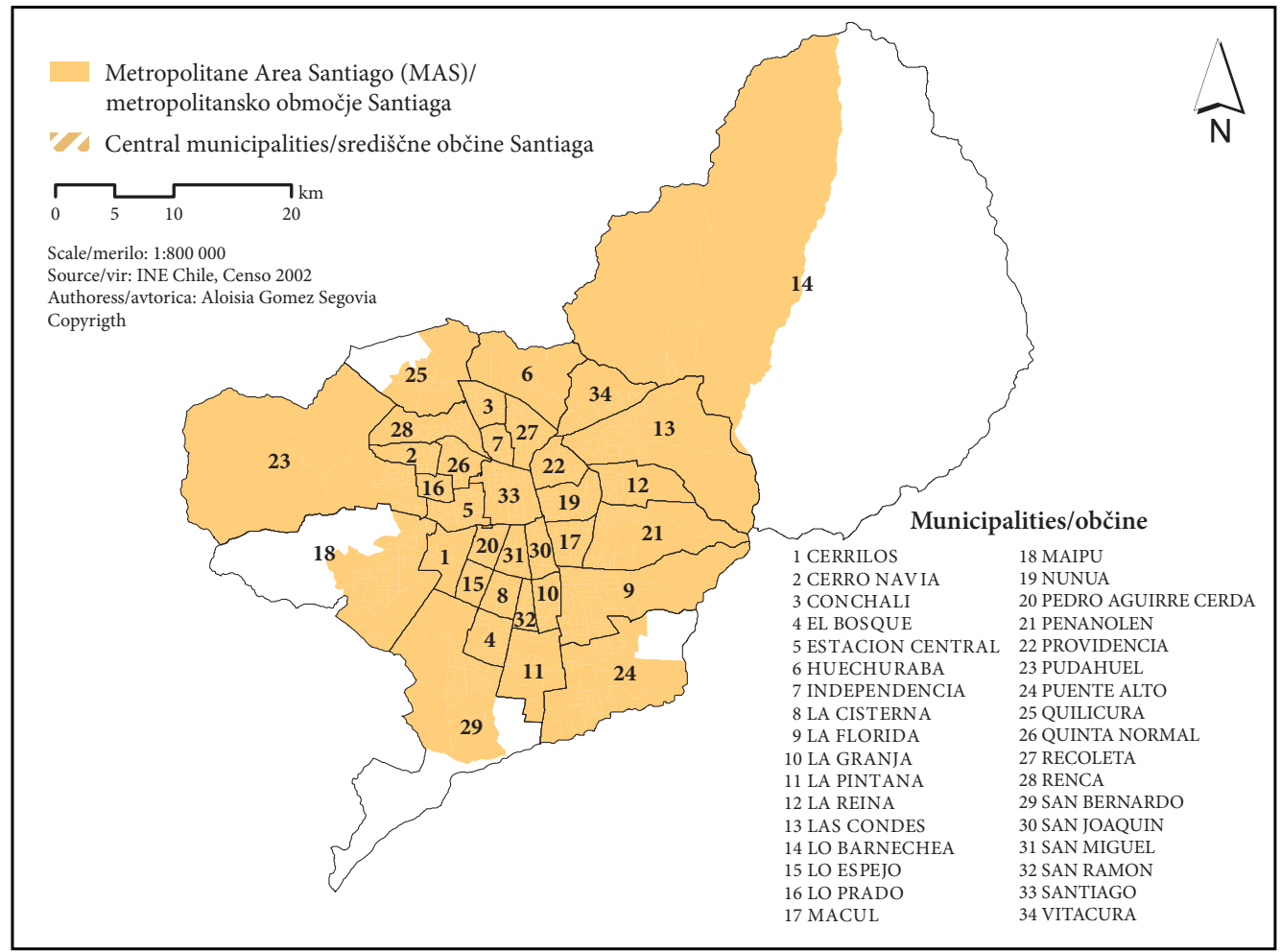

Figure 1: »El gran Santiago«, classification according to municipalities 2002. 
ipality Santiago (34), which includes the old city centre. During the research we added also the municipality of Las Condes (13) as an example of a municipality with prevailing upper social class population.

In the northeastern part of Santiago the municipalities of Las Condes, Vitacura and Lo Barnechea are located. The population of these municipalities mainly belongs to upper social classes. In 1992 more than $60 \%$ of the population of Las Condes and Vitacura was part of the highest socio-economic group ABC 1. The classification into socio-economic groups was calculated on the basis of income indicators, the employment and the education of the »household-leader" (Ducci 1998).

\section{Cartographic illustration of the spatial research on various levels}

In the figures the spatial distribution of Peruvian immigrants in Santiago is seen through statistical units (survey districts), as determined by the National Statistical Institute of Chile. These are area units, which are smaller than the district areas and because of that enable a far more detailed spatial research.

The percentage groups of Peruvian immigrants were determined on the basis of the computer program ARC MAP with the use of the so called natural breaks. 29.168 Peruvian immigrants lived in the metropolitan area of Santiago in 2002.

The spatial distribution in the metropolitan area shows a clear tendency of Peruvian immigrants to live in central survey districts. The share of Peruvian immigrants in the studied central statistical units represents more than $10 \%$ of the entire population of these areas. Some survey units reach even higher values, even more than $20 \%$ of Peruvian immigrants. In the central survey districts the share of female and male immigrants is quite comparable. On the contrary, in the northeastern parts of Santiago, where
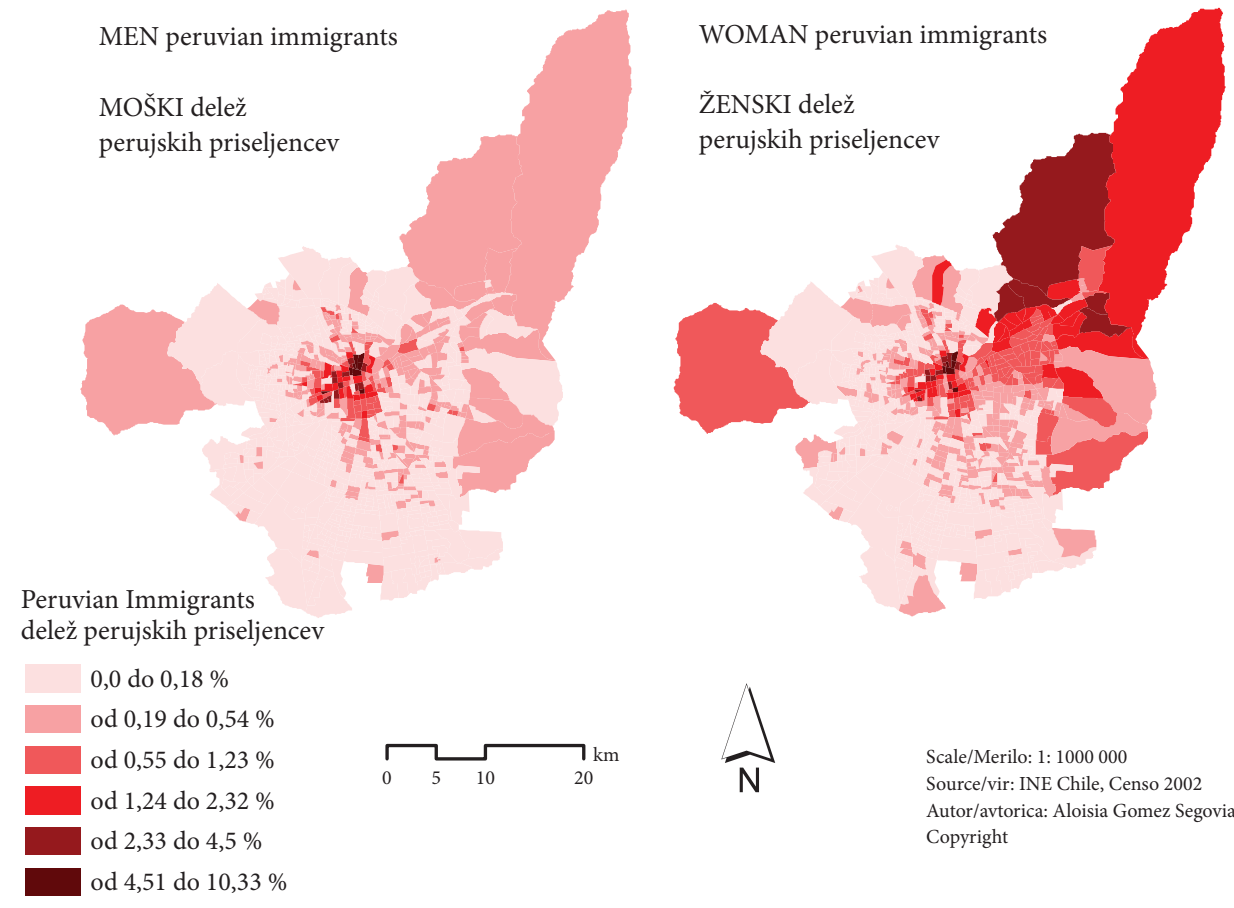

Scale/Merilo: 1: 1000000

Source/vir: INE Chile, Censo 2002

Autor/avtorica: Aloisia Gomez Segovia Copyright

Figure 2: The share of Peruvian immigrants among the entire population regarding gender, Santiago metropolitan area, 2002. 

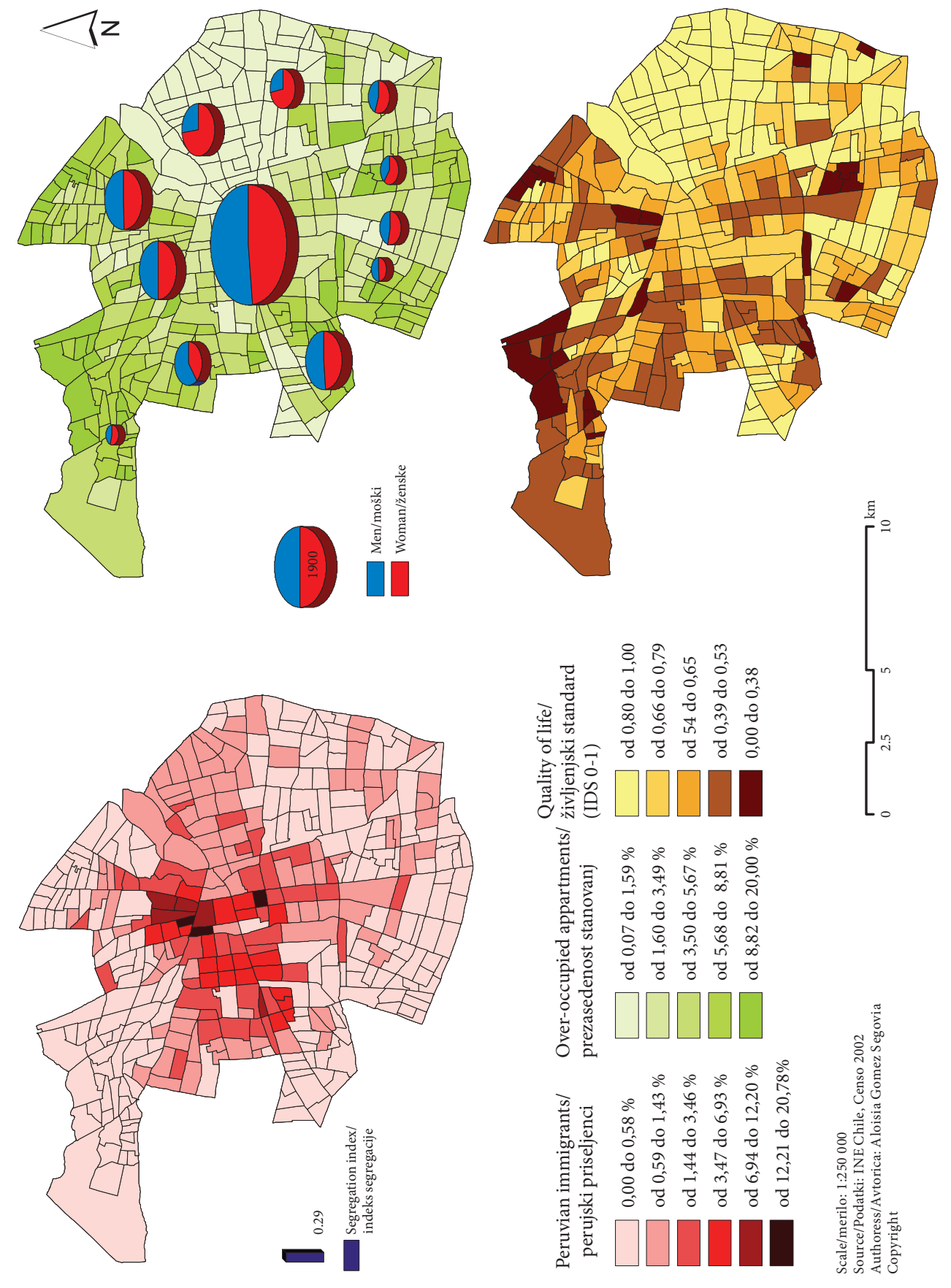
Figure 3: The share of Peruvian immigrants among the entire population, the segregation index, crowded housing conditions, living standard, central municipalities of Santiago 2002.

the share of immigrants is also quite large, female immigrants dominate over male $(4.5 \%$ and $0.54 \%$, respectively) (Figure 2). In the western part of the city the survey district of the Pudahuel municipality stands out, where the share of Peruvian immigrants is slightly higher and where again female immigrants, who reach the shares up to $1.23 \%$, are predominant. In all other survey districts outside the central municipalities towards the south and west of the metropolitan area, the share of Peruvian immigrants is extremely low and reaches only $0.19 \%$ or even $0 \%$.

We raised the question why is the share of Peruvian female immigrants in the northeastern part of Santiago so high, seeing that the inhabitants of northeastern municipalities of Las Condes or Vitacura are usually part of upper social classes. It is also interesting that the shares of women as well as men in central survey districts of the metropolitan area are the highest. With this reason the focal point of the Peruvian immigrants on the level of central municipalities of Santiago was studied even in greater detail.

The centre of the researched area on the level of central municipalities is represented by the municipality of Santiago, to which we added 11 more municipalities on the outskirts. About 10,000 Peruvian immigrants, according to the population register from 2002, live in these municipalities, what amounts to more than a third of all Peruvian immigrants living in the metropolitan area of Santiago.

The highest density of Peruvian immigrants, taking into account the aforementioned twelve municipalities (Figure 3), is located on the intersection of the central municipality of Santiago with the municipalities of Recoleta and Independencia. Our assumption was that there will be a strong correlation between the higher number of Peruvian immigrants and the higher level of crowded housing conditions and the lower living standards of the population.

The segregation index was calculated according to the formula provided by Duncan and Duncan 1955 (cited after Husa and Wohlschlägl 2005). This gives a measurement number on the uneven distribution of Peruvian immigrants in the area across various municipalities. The index span extends from 0 to 1 , where 0 represents a state without segregation and 1 a complete spatial segregation. A good illustration of the segregation is the comparison of the measurement number with the distribution of Peruvian immigrants according to smaller spatial survey districts. Municipalities with the highest indexes of segregation (Recoleta, Independencia in Estación Central) are, alongside the aforementioned intersecting municipalities, also those municipalities, which in some survey districts around the central municipality of Santiago reach an extremely high share of Peruvian immigrants. The lowest segregation index can be found at the municipality of Providencia, because the shares of Peruvian immigrants in almost all studied statistical units belong to the same group (from $0.59 \%$ to $1.43 \%$ ). The segregation index of the central municipality of Santiago is not as high $(0.34 \%)$, as higher shares of Peruvian immigrants are in the survey districts of the central municipality quite evenly distributed.

Because of the fact that immigrants often live in bad living conditions, we also investigated the aspect of crowded housing conditions according to survey districts and the share of Peruvian immigrants in central municipalities regarding gender. The indicator of crowded housing conditions (hacinamiento) extends from 0 to 100. We regard an apartment as (over)crowded, if more than 2.5 persons have to sleep in just one room. Numerous households point to overcrowding housing conditions, with higher percentages being found in survey districts. In the studied research area of central municipalities the percentages of crowded housing conditions extend from $0.07 \%$ to $20 \%$. At first glimpse, we can say that higher values are mainly found in the survey districts on the outskirts.

The third cartogram (Figure 3) represents the living standard of inhabitants according to survey districts of central municipalities. It was calculated with the index of socio-economic development (Borsdorf and Hidalgo 2004). The index has three parts. The first part can be calculated with the help of luxury items, such as cars, fridges, TVs, internet in possession by respondents. In the second part we compared the education level of the population according to survey districts, while the third part was determined by three variables of the quality of residence (roof, floor, walls). The index span extends from 0 to 1 , where 0 represents a very low and 1 a very high quality of living. The distribution of the quality of life paints quite a similar picture, as that of the cartogram of crowded housing conditions. This is not surprising, as we can assume that higher levels of crowded housing conditions are to be found in areas with lower living standards. Figure 3 clearly shows the correlation between these two indicators. 


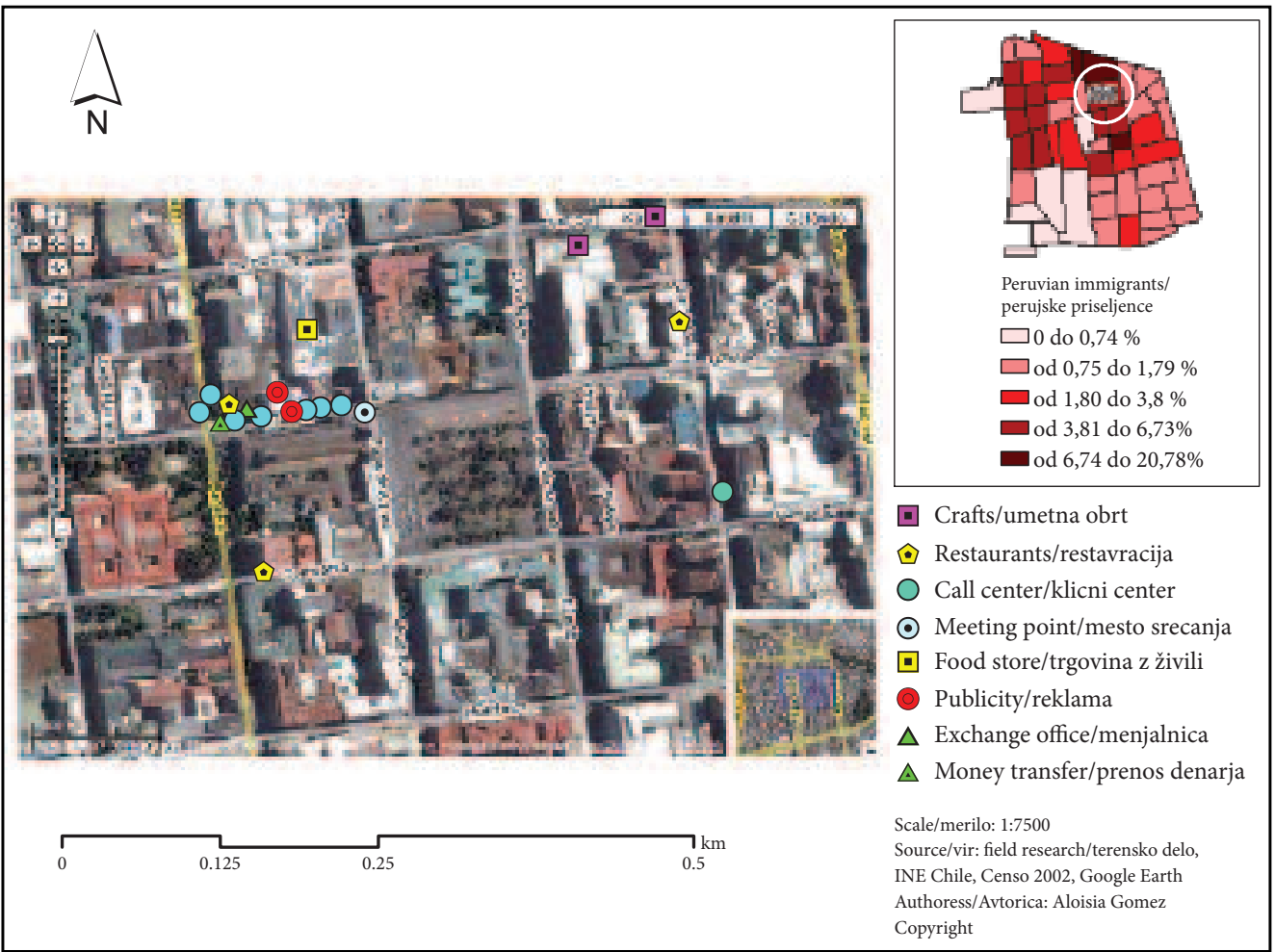

Figure 4: Peruvian shops in the vicinity of the central square Plaza de Armas, 2007.

Crowded housing conditions are extremely low in the eastern part of the city, in the municipalities of Providencia and Nunoa, while the quality of living there is relatively high. In these two municipalities the share of Peruvian female immigrants is rather high.

Comparison of the distribution of Peruvian immigrants with the crowded housing conditions index or with the living standard index does not reveal any important correlation at first glimpse. Higher shares of Peruvian immigrants are found in the centre, while higher shares of crowded housing conditions and lower living standard in the suburbs. A more detailed comparison of survey districts with the higher shares of Peruvian immigrants, especially in the intersecting municipalities of Santiago, Independencia and Recoleta, gives a sample of the correlation between higher shares of crowded housing conditions and lower living standard. There are some individual survey districts with high numbers of Peruvian immigrants, higher living standard and the lower shares of crowded housing conditions. The aforementioned correlation of lower living standards with the high share of Peruvian immigrants in intersecting municipalities is only a small tendency seen through an indicator.

From the twelve central municipalities of Santiago, the municipality of Santiago has the highest number of Peruvian immigrants. In 2002 the municipality of Santiago was home to 4.099 Peruvians, which amounted to $41 \%$ of all Peruvian immigrants of central municipalities. Therefore the central municipality of Santiago was chosen as the third level of our research study. The area also includes the old city centre, which has been the most affected by the Peruvian immigration since 1995.

In the central survey district which includes the central square of Santiago Plaza de Armas, the share of Peruvian immigrants amounts to $4.01 \%$. A relatively high share of Peruvian immigrants is visible mainly in the area of the central square and its vicinity. The centre of all the happenings is in the northwestern corner of the square, which is the first place for many Peruvian immigrants where they can contact their fellow countrymen. The majority of Peruvians, who share this meeting place, are unemployed, and they 

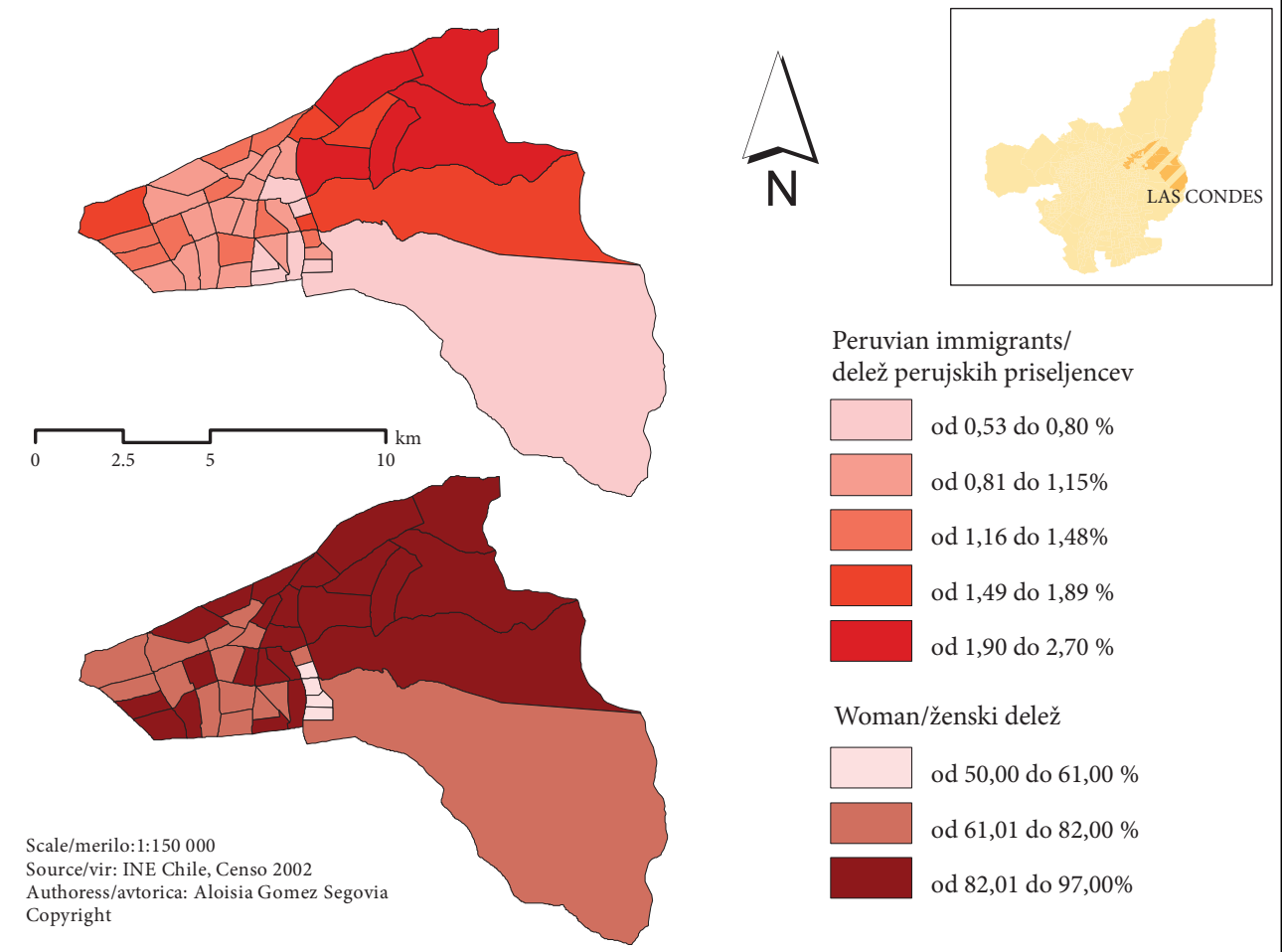

Peruvian immigrants/

delež perujskih priseljencev

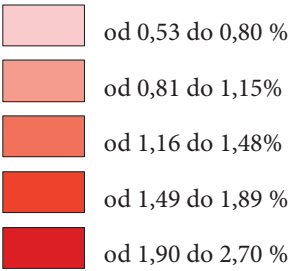

Woman/ženski delež

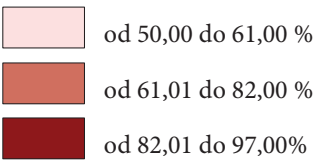

Figure 5: The share of Peruvian immigrants, the share of female immigrants, the municipality of Las Condes 2002.

see this place as an opportunity of finding employment. The vicinity of the main square is named la Lima chica - Little Lima (Luque Brazan 2007; Stefoni 2007b). This part of the square also has the most Peruvian shops and offices, which are mainly organized as call-centres, which offer cheap calls, mainly to Peru, as shown by the numerous signs and ads. The same street is also home to an exchange office and the service for money transfers (»Peru Courier Service«). Close by are also a Peruvian restaurant and a Peruvian grocery shop. The presence of Peruvians is once again shown by numerous ads, the first of which advertizes the Peruvian radio show »tardes peruanas « - »Peruvian evenings «, a show which is on air from Monday to Friday. The second sign advertizes numerous shops in the underground passage, which include also one Peruvian shop.

The studied area also included three Peruvian restaurants and two shops with Peruvian craftsmanship goods. Although the share of Peruvians in regards to the entire population is relatively small, their presence is quite obvious and also leaves a mark on some city streets.

One of the most obvious findings of our research is also that areas, where we found higher shares of Peruvian female immigrants (mostly northeast), are mostly areas with higher living standards (Figures 2 and 3). With this reason we studied the municipality of Las Condes in great detail, as this municipality lies in the northeastern part of the city and is an example of a municipality with upper class population.

Las Condes, alongside the two neighbouring municipalities up north (Vitacura and Lo Barnechea) and the neighbouring municipality of Providencia to the west, is among the richest municipalities of Santiago. In 1996 more than half of the richest inhabitants of Santiago was living in the municipalities of Providencia, Las Condes and Vitacura. This points to the eruption and development of social inequality as well as to the polarization of the metropolitan area of Santiago, which has been for a long time the research topic of many researchers (Borsdorf, Bähr and Janoschka 2002). In the municipality of Las Condes the average share of Peruvian female immigrants is extremely high (82\%). Compared to the central municipalities of the metropolitan area of Santiago the share of Peruvian immigrants in the municipality of Las 
Condes is lower. The higher concentration of Peruvian immigrants in the north of the municipality reaches $2.7 \%$ above the entire population of statistical units. To the south of the municipality the share of Peruvians is lower (from 0.58 to $0.80 \%$ ). The structure of immigrants in the municipality shows great dominance of female immigrants, as in some parts the share of female immigrants is even as high as $97 \%$. In other survey districts towards the south and west the shares of female immigrants are high as well, extending from $61.01 \%$ to $82 \%$. Only four, in the aspect of size, extremely small survey districts have a lower share of Peruvian female immigrants, from $50 \%$ to $61 \%$ (Figure 5 ).

The studied spatial distribution of Peruvian immigrants in this chapter shows very interesting results and at the same time raises some questions, as for example the question of the predominant share of female immigrants in the northwestern, richer municipalities of Santiago. Contemporary authors (Martinez 2003; Huatay 2005; Stefoni 2007b) characterize the new Peruvian immigration after 1995 as a work migration of the lower social classes. It is our intention to address and confirm this statement in the following, fourth chapter. The structure of the population of Peruvian immigrants to Santiago should give insight into the tendencies for the dominance of Peruvian female immigrants in the northwestern part of the metropolitan area of Santiago.

\section{The structure of Peruvian immigrants in Santiago (Chile)}

The research of the structure of Peruvian immigrants should give answers to some still unanswered questions from the research of spatial distribution, and possibly result in some findings about the reasons and types of migration. The research was based on the following questions:

- Why such distribution of Peruvian immigrants in Chile?

- Why is the share of female immigrants predominant in the northeastern urban area of Santiago?

- What are the activities the Peruvian immigrants most commonly employ?

- Which age groups are the most dominant?

- Does data about the social status of Peruvian immigrants exist?

The research of the structure of immigrants included data from the last population register from 2002. The results were compared among different levels, mentioned already in the introduction: the metropolitan

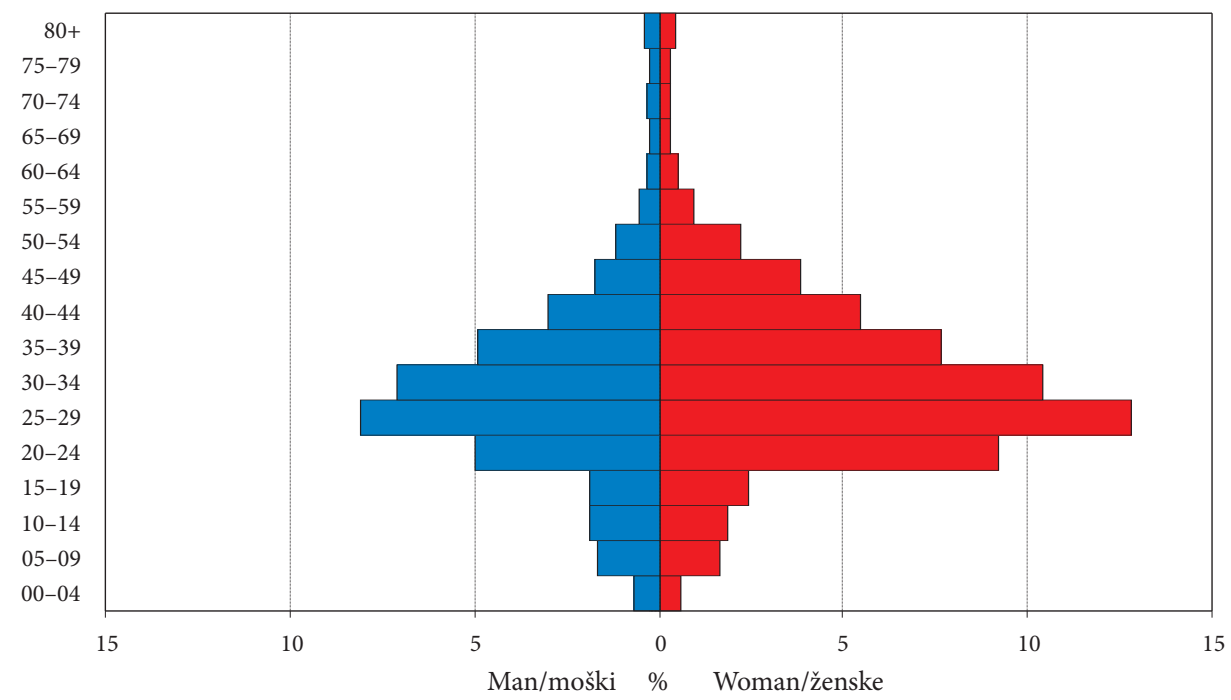

Figure 6: Age and gender structure of Peruvian immigrants, the metropolitan area of Santiago 2002 (source: INE Chile, Censo 2002). 


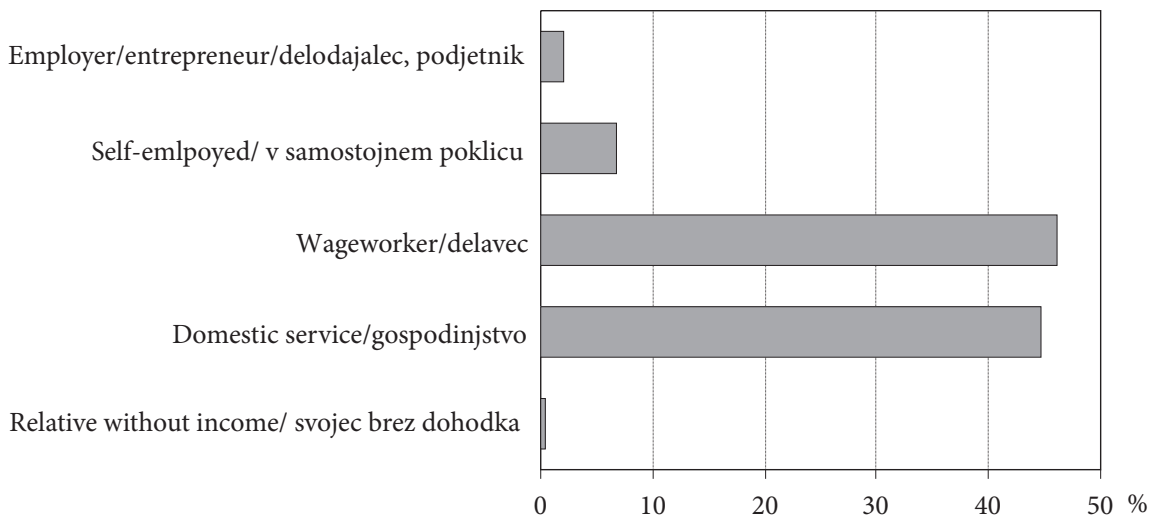

Figure 7: The distribution of Peruvian immigrants regarding employment, metropolitan area of Santiago 2002 (source: INE Chile, Censo 2002).

area of Santiago (level 1) and the municipalities of Santiago and Las Condes (level 3). The article will deal only with those comparisons for which we determined significant differences, or better said, for which we found answers to the questions posed. With this reason we will also show the demographic structure, with the indicators of age, employment, social and gender structure.

The age pyramid of Peruvian immigrants in the metropolitan area of Santiago shows that the majority of Peruvian immigrants is aged between 20 and 40 years (Figure 6). The share of children and older people is really low. The smallest shares are for the age group between 0 and 4 and the age group of 60 and above. The pyramid shows that almost all Peruvian immigrants in Santiago are part of the workforce-group contingency. This confirms the thesis about the work migration of Peruvian immigrants in Santiago. The age pyramid also points out the higher share of female immigrants, with the biggest share being presented by the young Peruvian female immigrants, aged 25 to 29 .

The employment quota of work-active population of Peruvian immigrants of the metropolitan area of Santiago amounts to $76.22 \%$, while the unemployment quota of the same group is $7.30 \%$. In the central municipality of Santiago the employment quota is a bit lower $(72.07 \%)$ and the unemployment quota slightly higher (11.22\%). In the municipality of Las Condes the employment quota is substantially higher $(88.84 \%)$ and the unemployment quota extremely low $(1.98 \%)$.

The employment structure of Peruvian immigrants was compared on the basis of the employment position. Within the metropolitan area of Santiago we determined two focal points (photo 7). The first focal point is represented by $46 \%$ of workers, while the second is represented by $44.71 \%$ of household-servants. Both groups together cover $90.73 \%$ of all Peruvian immigrants of the metropolitan area. All the remaining Peruvian immigrants work individually $(6.84 \%)$ as managers or entrepreneurs $(2.10 \%)$, while only $0.33 \%$ remain without work.

The comparison of the municipalities of Santiago and Las Condes establishes very interesting differences. In the central municipality of Santiago the focal point is represented by the group of workers $(60.86 \%)$, with the second group of household-servants amounting to $27.47 \%$. On the other hand, in the municipality of Las Condes, where the share of female immigrants is dominant, the picture is reverse, with the first focal point being represented by household-servants $(77.10 \%)$, while the group of workers amounts only to $18.19 \%$.

The social structure of Peruvian immigrants was defined by the indicators of the highest level of education and the living conditions of Peruvian immigrants. The research of the income structure was not possible, because of the lack of adequate data. The social structure can also be studied on the basis of the aforementioned employment structure. 


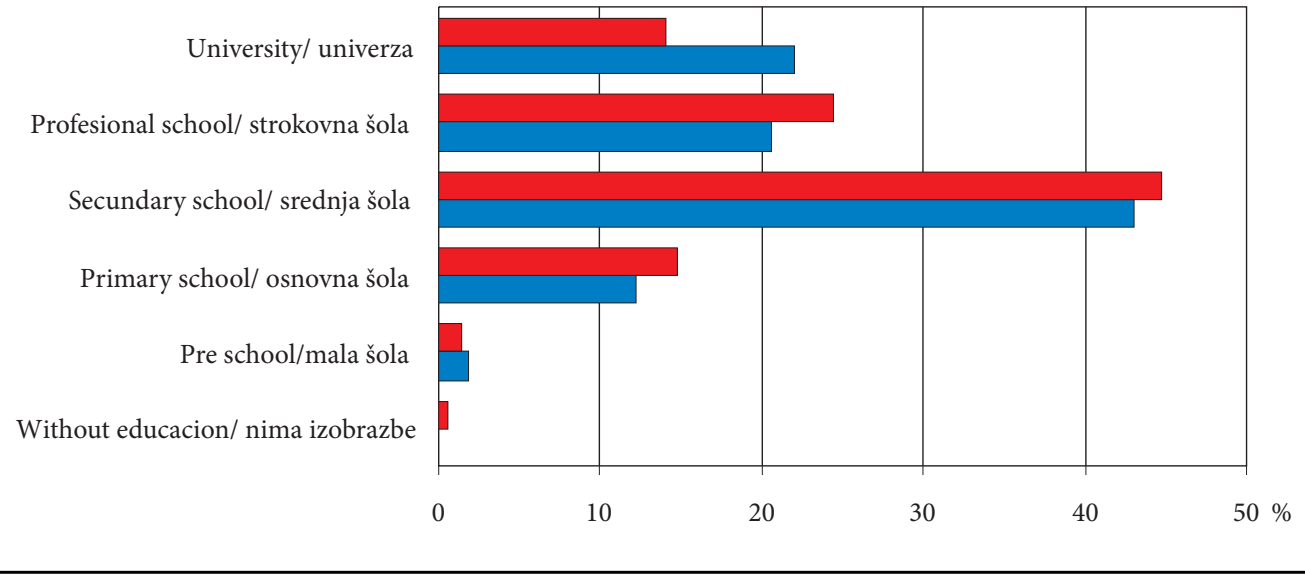

Figure 8: The highest level of education of Peruvian immigrants, metropolitan area of Santiago 2002 (Source: INE Chile, Censo 2002).

More than $80 \%$ of Peruvian immigrants in the metropolitan area of Santiago have finished high school, college or university (Figure 8). The level of education of Peruvian immigrants is relatively high. 14.14\% of Peruvian male and $16.18 \%$ of Peruvian female immigrants have a lower level of education (up to the finished primary school). Only $0.18 \%$ of Peruvian male and $0.58 \%$ of Peruvian female immigrants have no education whatsoever. The bigger difference among both genders lies only with the university education, where the Peruvian male immigrants are predominant.

The comparison of levels of education between the municipalities of Santiago and Las Condes shows a better educational structure in the municipality of Las Condes, where more Peruvian immigrants acquired university education.

Different types of living conditions allow us to divide the immigrants into 6 categories (photo 9). The majority of immigrants live in houses $(62.27 \%)$, followed by those living in apartments $(20.61 \%)$. The third group of immigrants lives in the so called »conventillo« - a small convent (12.24\%). »Conventillo« is a special category of one bedroom-apartments within quadrant blocks of flats in the old city centre of

Travellers (no appartment)/ popotniki (nima stanovanja)

Collective appartments/kolektivna stanovanja

Other (poor) living forms/ druge (revnejše) vrtse bivanja

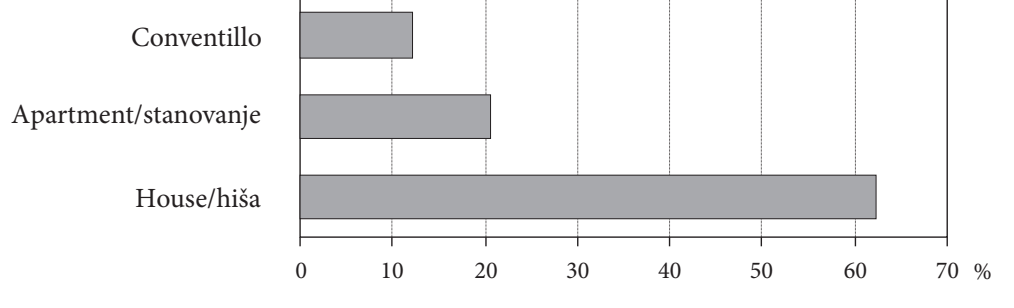

Figure 9: The living conditions of Peruvian immigrants, metropolitan area of Santiago 2002 (source: INE Chile, Censo 2002). 


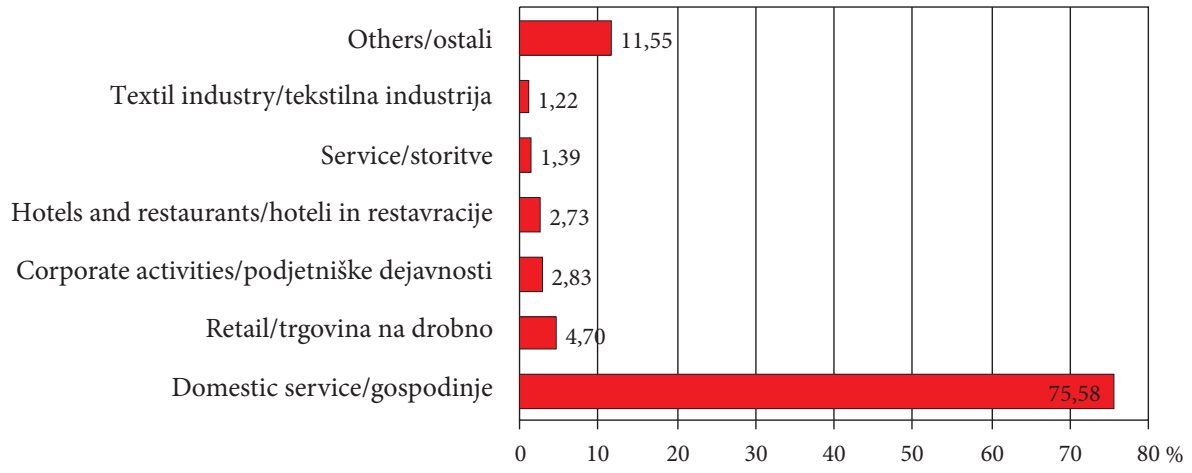

Flgure 10: The main areas of employment of Peruvian women, metropolitan area of Santiago 2002 (source: INE Chile, Censo 2002).

Santiago. The rooms are distributed alongside the common hallway, where there is also a joined toilet. »Conventillo« is an old form of living, which was primarily intended for lower classes. »Conventillos« were in Santiago the first goal of immigrants already in time of the population's migrations from rural to urban areas (Borsdorf, Bähr, Janoschka 2002).

The comparison between the central municipality of Santiago and the municipality of Las Condes, located to the northeast, shows an important difference. The type of living in »conventillos « is in Santiago quite common (31.81\%), while in the municipality of Las Condes it doesn't even exist. The majority of Peruvian immigrants in the latter municipality lives in houses $(60.74 \%)$ and the rest in flats. As we mentioned before, mainly Peruvian female migrants live in Las Condes, where they work mainy as household-servants. The high shares of immigrants, living in houses or flats, clearly show that these Peruvian servant-women live in houses of their employers (domestic in service).

We already showed the gender structure of Peruvian immigrants (chapter 3). 61\% of Peruvian immigrants in the metropolitan area are female. Figures 10 and 11 show the main employment areas of Peruvian

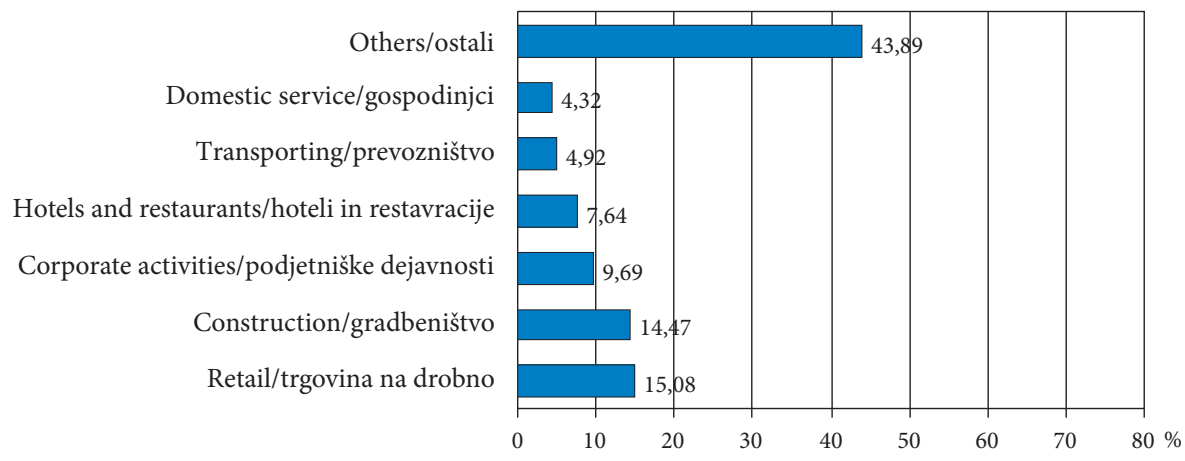

Figure 11: The main areas of employment of Peruvian men, metropolitan area of Santiago 2002 (source: INE Chile, Censo 2002). 
immigrants according to gender. Out of more than 90 different forms of employment, we focused only on six most important ones. It is obvious that Peruvian female immigrants mostly work as household-servants $(75.58 \%)$, while on the other hand Peruvian male immigrants are employed in various branches. We only indicated the main areas, where more than $4 \%$ of Peruvian immigrants are employed. These fields include retail trade, construction works, entrepreneurship activities, hotels and restaurants, transport services and household help.

\section{Conclusion}

The spatial distribution and the demographic structure of Peruvian immigrants in the city of Santiago are very interesting but has not yet been presented in the Slovenian geographical literature (Zorn and Komac 2009). The majority of Peruvian immigrants live in central survey districts of Santiago. Their presence is demonstrated by numerous Peruvian shops, especially in the vicinity of the main square Plaza de Armas. The services for money transfer and call-centres are also visible signs of trans-nationalism, as this is the only way of immigrants staying in touch with their homeland. Work migration is predominant, as confirmed by the age pyramid and a high percentage of employment. Peruvian immigrants are predominantly aged between 20 and 40 . Among immigrants there are only a few Peruvian children and older people, aged above 60 .

We also determined that there are more female than male immigrants and that the majority of them work as house-servants and live with families, for whom they work. The share of Peruvian women is high mainly in richer municipalities in the northwestern part of Santiago. The cartographic comparison of central municipalities also showed the tendency in correlation between the higher share of Peruvian immigrants, the crowded housing conditions and the lower quality of living. In the analysis of social structure we determined a relatively high level of education of Peruvian immigrants, especially those living in richer municipalities.

The most important living arrangements of immigrants are houses, flats and in the old city centre one-room apartments (conventillos). The social status of Peruvian immigrants is hard to determine. One-room apartments (conventillos) in the old city centre of Santiago are mostly reserved for lower social classes. The correlation between the occupation and the way of living is most obvious in richer parts. Peruvian immigrants namely live and work in houses or flats of other families, which is a sign of lower social classes.

A different picture is painted by the level of education, which is relatively high. The article also illustrated the distribution and the structure of Peruvian immigrants in Santiago. We came to interesting conclusions, which cannot be generalized due to the lack of data. We only took into account the registered immigrants, but there are bound to be plenty more those, who do not have their legal status. This is also another reason, why some of our questions still remain unanswered.

\section{Literature}

Borsdorf, A., Bähr, J., Janoschka M. 2002: Die Dynamik stadtstrukturellen Wandels in Lateinamerika im Modell der lateinamerikanischen Stadt. Geographica Helvetica 57-4. Basel.

Borsdorf, A. 2003: Como modelar el desarollo y la dinámica de la ciudad latinoamericana. EURE 29-86. Santiago.

Internet: http://www.scielo.cl/scielo.php?pid=S0250-71612003008600002\&script=sci_arttext (5.6.2008).

Borsdorf, A. 2004: Landflucht als Teil der Mobilitätstransformation. Das Beispiel Lateinamerika. Praxis Geographie 7-8. Braunschweig.

Borsdorf, A., Hidalgo, R. 2004: Vom Barrio Cerrado zur Ciudad Vallada. Neue Dimensionen der sozialen und funktionalen Exklusion in Santiago de Chile. Mitteilungen der Österreichischen Geographischen Gesellschaft 146. Wien.

Ducci, M.E. 1998: Santiago, ¿Una mancha de aceite sin fin? ¿Que pasa con la población cuando la ciudad crece indiscriminadamente? EURE 24-72. Santiago.

Internet: http://www.scielo.cl/scielo.php?script=sci_arttext\&pid=S0250-71611998007200005 (2.4.2008). 
Hidalgo, R., Borsdorf, A., Zunino, H. 2008: Las dos caras de la expansión residencial en la perifería metropolitana de Santiago de Chile: precariopolis estatal y privatópolis inmobiliaria. Producción inmobiliaria y reestructuración metropolitana en América Latina. Geolibros 11. Sao Paulo, Santiago.

Huatay, C., Jimenez, R. 2005: »Algo esta cambiando. Globalización, migración y ciudadanía en las asociaciones de peruanos en Chile«. Santiago.

Husa, K., Wohlschlägl H. 2005: Proseminar "Grundzüge der Bevölkerungsentwicklung. Lehrbehelf zur Lehrveranstaltung. Institut für Geographie und Raumforschung der Universität Wien. Wien.

INE 2002: Censos de población 2002. Santiago. Internet: www.ine.cl (5.9.2008).

INEI-DIGEMIN-OIM, 2008: »Perú, estadísticas de la migración internacional de peruanos 1990-2007«. Lima.

Janoschka, M., Borsdorf A. 2005: »Condominios fechados. The rise of private residential neighbourhoods in Latin America«. Private Cities. Global and Local Perspectives. London, New York.

Luque Brazan, J. C. 2007: Asociaciones políticas de inmigrantes peruanos y la »Lima Chica en Santiago de Chile. Migraciones internacionales 4-2. Ciudad de Mexico.

Martinez Pizarro, J. 2003: El encanto de los datos. Sociodemografía de la inmigracion en Chile según el censo de 2002. CEPAL, Serie Población y desarollo 49. Santiago.

Stefoni, C. 2007a: La migración en la agenda chileno-peruana. Un camino por construir. El Caso Enron. Principales aspectos contables de auditoría y de gobierno corporativo. Santiago.

Stefoni, C. 2007b: Inmigrantes transnacionales: la formación de comunidades y la transformación en ciudadanos. Facultad Latinoamericana de Ciencias Sociales, Sede. Santiago.

Zorn, M., Komac, B. 2010: The History of Acta geographica Slovenica. Acta geographica Slovenica 50-1. Ljubljana. DOI: 10.3986/AGS50101 


\section{Prostorska raziskava perujskih priseljencev v Santiagu}

DOI: $10.3986 /$ AGS51109

UDK: 911.3:314.151.3-054.72(83)

COBISS: 1.01

IZVLEČEK: Prispevek predstavlja rezultate socialno-prostorske raziskave perujskih priseljencev v čilskem glavnem mestu Santiago (Čile). Stalna migracija Perujcev v Santiago se je v začela na začetku devetdesetih let prejšnjega stoletja in je zlasti od leta 1995 naprej zelo hitro naraščala. Za Argentinci so Perujci druga največja skupina priseljencev v Čilu, v urbanem območju Santiaga pa so Perujci celo največja priseljenska skupina. Opazna je zlasti zgostitev perujskih priseljencev v starem mestnem jedru, kar je spodbudilo pozornost čilske družbe, medijev in nekaterih znanstvenikov. S demografskimi podatki iz leta 2002 želimo prikazati strukturo perujskih priseljencev ter z zemljevidi vizualizirati njihovo prostorsko porazdelitev.

KLJUČNE BESEDE: geografija, migracije, perujski priseljenci, demografska sestava, meddržavna migra cija, Santiago (Čile)

Uredništvo je prejelo prispevek 18. oktobra 2010.

NASLOV:

mag. Aloisia Gomez Segovia

Dornach 18, A - 9162 Strau, Austria

E-pošta: aloisiagomez@gmail.com

\section{Vsebina}

$1 \quad$ Uvod

205

2 Območje prostorske raziskave perujskih priseljencev

206

3 Kartografski prikaz prostorske raziskave po različnih ravneh

Struktura perujskih priseljencev

v Santiago (Čile)

Sklep

6 Literatura

210 


\section{Uvod}

Mednarodna stalna migracija Perujcev v sosednjo državo Čile se je začela okoli leta 1990. Istega leta je gospodarstvo v Peruju pod vodstvom predsednika Alana Graciana doživelo zelo hudo recesijo. Prišlo je do hiperinflacije z velikanskim vzponom, ki je dosegel nad $7000 \%$. Med prebivalci je to seveda povzročilo zelo visoko brezposelnost in hudo revščino. Še istega leta je vlado prevzel Alberto Fujimori, ki je nato leta 1992 z državnim udarom vzpostavil diktaturo.

Nasprotno temu se je v Čilu leta 1990 končala sedemnajst-letna diktatura, ponovno so vzpostavili demokracijo in zato je prišlo do politične stabilizacije države.

Od leta 1973 naprej, ko je Augusto Pinochet z vojaškim pučem proti socialistični vlade Salvadorja Allendeja nasilno ustanovil diktaturo, se je v Čilu tudi začelo krmiljeno prestrukturiranje gospodarskega reda. Nova gospodarska politika se je naslonila na premise čikaške šole ter multilateralne organizacije, kot so svetovna banka in mednarodni monetarni sklad (Luque Brazan 2007). Novi kapitalistični gospodarski sistem je zlasti vplival na urbano, politično, gospodarsko in socialno središče, na glavno mesto Santiago (Čile). Prišlo je do deregulacije zemljiškega trga in do razširitve oziroma odprave mestne meje. Prebivalci z višjim socialnim statusom so se zaradi boljše kakovosti življenja začeli seliti iz starega mestnega jedra na obrobne cone mesta, kjer niso bili več izpostavljeni zvočnemu in zračnemu onesnaženju (Janoschka in Borsdorf 2005; Hidalgo, Borsdorf in Zunino 2008). Začela se je faza suburbanizacije. V Santiagu so se pozidane površine med letoma 1990 in 1995 povečale za 10000 ha (Ducci 1998). Po modelu mestnega raz voja latinskoameriških mest (Borsdorf, Bähr in Janoschka 2002) se je že v sedemdesetih letih začela četrta in še vedno aktualna faza rekonstrukcije, kjer se kompaktno mesto $\mathrm{z}$ mestnimi obroči začne fragmentirati v večjedrno mesto in raste kot oljni madež (Ducci 1998; Borsdorf 2003). Mestni razvoj v Santiagu dobro prikaže doslednost neoliberalne gospodarske transformacije s številnimi privatizacijami, izgubo vloge državne vlade v konkurenčnem tržnem gospodarstvu.

Razširitev mestnega robu je povzročila praznjenje prebivalstva v starem mestnem jedru Santiaga, izpraznjena območja mestnega središča pa so zaradi nižjih cen stanovanj postala cilj perujskih priseljencev.

Prvi perujski priseljenci na začetku 90 letih so bili predvsem politični begunci. Ko se je v Čile vrnila demokracija, so v Santiagu ustanovili urad Združenih narodov za zadeve političnih beguncev (ACNUR), v prvi vrsti zaradi pol milijona čilskih političnih beguncev v eksilu, ki so se začeli vračati v domovino. Čil ska vlada ter organizacije pa pravno in institucionalno niso bili pripravljeni še na politične begunce iz Peruja (Luque Brazan 2007).

Od leta 1995je delež perujskih priseljencev zelo hitro naraščal. Začela se je nova perujska imigracija urbanega značaja, nižjega socialnega statusa in predvsem tudi delovnega značaja (prim. Martinez 2003; Stefoni 2007a). Za Argentincih so Perujci druga največja skupina priseljencev v Čilu, v urbanem območju Santiaga pa so celo največja. Med letom 1992 in 2002 je perujska imigracija v Čilu narasla za več kot $350 \%$. V istem obdobju je skupina Argentincev narasla samo za $45 \%$. Do leta 2002 se je več kot $80 \%$ peruj skih priseljencev Čila priselilo samo v glavno mesto Santiago (Huatay in Jimenez 2003).

Pozornost čilske družbe se od 90 letih naprej nanašala na perujsko manjšino. Čilski časopisi so pisali o množičnem priseljevanju, o valovih perujskih priseljencev, statistični podatki pa kažejo, da je delež perujskih priseljencev v Čilu leta 2002 predstavljal le $0,36 \%$ celotnega prebivalstva. V primerjavi z drugimi tradi cionalnimi državami priseljevanja je to zelo majhen delež priseljencev. Vendarle je zelo zanimivo, da se je perujska manjšina $\mathrm{v}$ Santiagu $\mathrm{v}$ zadnjih letih tako hitro povečala.

V članku želimo prikazati prostorsko porazdelitev perujskih priseljencev v urbanem središču Santiaga ter s demografskimi podatki predstaviti tudi njihovo strukturo, kot so starostna, zaposlitvena, socialna in spolna struktura perujskih priseljencev.

Kvantitativne statistične podatke za raziskavo smo pridobili iz Nacionalnega statističnega inštituta Čila (Instituto nacional de estadistica - INE), ki vsakih deset let objavi nov popis prebivalstva. V aktualni raziskavi perujskih priseljencev smo uporabili podatke iz najnovejšega popisa prebivalstva leta 2002. Opozoriti je treba na dejstvo, da v popisih prebivalstva niso šteti nedokumentirani priseljenci. Po vsej verjetnosti pa predstavljajo nedokumentirani perujski priseljenci v Santiagu zelo pomemben delež, dejansko števi lo se pa lahko le ocenjuje. Tudi sicer je težko delati z migracijskimi podatki, kjer je to v bistvu poskus zajemanja gibanja oziroma premikov. Ob popisu leta 2002 je bilo v Čilu 38.000 perujskih priseljencev, zunanje ministrstvo Peruja pa število perujskih izseljencev v letu 2003 ocenjuje na več kot 81.000. Novejše raziskave Statistič nega inštituta Peruja (INEI), Mednarodne organizacije za migracije(OIM) ter s perujskega migracijskega 
zavoda (DIGEMIN) kažejo, da se je med letoma 1990 in 2007 več kot 180.000 Perujcev v Čile priselilo za vsaj šest mesecev. Leta 2007 je čilska vlada uvedla zakon o amnestiji, kjer je več kot 15.000 nedokumentiranih perujskih priseljencev izkoristilo priložnost za ureditev dovoljenj za bivanje.

Glede na omenjeno lahko domnevamo, da je delež nedokumentiranih perujskih priseljencev v Santiagu zelo pomemben, zaradi pomanjkanja podatkov pa jih v naši prostorski in demografski raziskavi nismo upoštevali.

\section{Območje prostorske raziskave perujskih priseljencev}

Območje raziskave perujskih priseljencev smo razdelili na tri ravni (glej slika 1).

Prva raven predstavlja metropolitansko območje Santiaga. Območje zajema izključno urbano površino in šteje 34 občin. Nekatere obrobne občine samo delno pripadejo urbani površini Santiaga. Predstavljeno območje se tudi imenuje el gran Santiago - veliki Santiago.

Na drugi ravni smo določili območje dvanajstih središčnih občin Santiaga, saj smo že od vsega začetka domnevali, da se perujski priseljenci večinoma nahajajo v središču mesta.

Tretjo raven predstavljata dve izbrani občini. Kot prvo smo izbrali središčno občino Santiago (34), v kateri je staro mestno jedro. V teku raziskave smo dodali še občino Las Condes (13) kot primer občine $s$ prebivalstvom višjega socialnega statusa.

Na severovzhodu Santiaga so občine Las Condes, Vitacura in Lo Barnechea. Tam živeči prebivalci spadajo večinoma v najvišji socialni sloj. Leta 1992 je namreč več kot $60 \%$ prebivalcev občin Las Condes in Vitacura pripadalo najvišji socioekonomski skupini ABC 1. Razdelitev v socialnoekonomske skupine je izračunana prek kazalnikov dohodka, poklicnega položaja in izobrazbe predstojnika gospodinjstva (Ducci 1998).

Slika 1: El gran Santiago, razčlenitev po občinah 2002.

Glej angleški del prispevka.

\section{Kartografski prikaz prostorske raziskave po različnih ravneh}

Na slikah smo prostorsko porazdelitev perujskih priseljencev v Santiagu prikazali prek statističnih enot (popisni okoliši), ki jih določa nacionalni statistični inštitut Čila. Gre za površinske enote, ki so manjše od površin okrajev in tako omogočajo podrobnejšo prostorsko raziskavo.

Skupine deležev perujskih priseljencev smo določili prek računalniškega programa ARC MAP z uporabo tako imenovane metode naravnih prelomov - natural breaks.

Na metropolitanskem območju Santiaga je leta 2002 živelo 29.168 perujskih priseljencev.

Slika 2: Delež perujskih priseljencev med celotnim prebivalstvom po spolu, metropolitansko območje Santiaga 2002.

Glej angleški del prispevka.

Prostorska porazdelitev na metropolitanskem območju pokaže jasno težišče perujskih priseljencev v centralnih popisnih okoliših (glej sliko 2). Delež perujskih priseljencev v centralnih obravnavanih statističnih enotah predstavlja več kot $10 \%$ celotnega prebivalstva teh površin. Nekatere popisne enote dosežejo celo višje vrednosti, tudi več kot $20 \%$ perujskih priseljencev. V centralnih popisnih okoliših je delež moških in ženskih priseljencev primerljiv. Nasprotno temu v severovzhodnih predelih Santiaga, ki imajo tudi raz meroma visok delež priseljencev, močno prevladujejo ženske (4,5\%); moških je le $0,54 \%$ (slika 2).

Na zahodu mesta izstopa še popisni okoliš občine Pudahuel, kjer je delež perujskih priseljencev malo višji in zopet prevladajo perujske priseljenke, ki dosegajo deleže do $1,23 \%$.

$\mathrm{V}$ ostalih popisnih okoliših zunaj centralnih občin proti jugu in zahodu metropolitanskega območ ja je delež perujskih priseljencev zelo nizek in pade pod $0,19 \%$ ali je celo na $0 \%$.

Porajalo se nam je vprašanje, zakaj je delež perujskih žensk na severovzhodu Santiaga tako visok, saj prebivalci severovzhodnih občin Las Condes ali Vitacura po navadi pripadajo višjemu socialnemu sloju. Zanimivo pa je tudi to, da so deleži žensk in tudi moških v centralnih popisnih okoliših metropolitanskega območja najvišji. Zaradi tega smo si težiščno območje bivanja perujskih priseljencev na ravni centralnih občin Santiaga še natančneje ogledali. 
Središče raziskovalnega območja na ravni centralnih občin predstavlja občina Santiago, kateri smo prišteli še enajst obrobnih občin (slika 1).V njih po popisu prebivalstva leta 2002 živi 9936 perujskih priseljencev, kar predstavlja $34 \%$ vseh perujskih priseljencev metropolitanskega območja Santiaga.

Slika 3: Delež perujskih priseljencev med celotnim prebivalstvom, indeks segregacije, prezasedenost stanovanj, življenjski standard, centralne občine Santiaga 2002.

Glej angleški del prispevka.

Najvišje zgostitve, upoštevaje omenjenih dvanajst občin, so (slika 3) v sečišču središčne občine Santiago z občinama Recoleta in Independencia. Že prej smo predvidevali močno povezavo med višjim številom perujskih priseljencev in višjo prezasedenostjo stanovanj ter nižjo raven življenjskega standarda prebivalstva.

Indeks segregacije je bil izračunan po formuli Duncan in Duncan 1955 (cit. po Husa in Wohlschlägl 2005). Gre za mersko število neenake razporejenosti perujskih priseljencev v prostoru. V našem primeru po različnih občinah. Razpon indeksa sega od 0 do 1 , pri čemer predstavlja 0 stanje brez segregacije in 1 popolno prostorsko segregacijo. Dobra ponazoritev segregacije je primerjava merskega števila s porazdelitvijo perujskih priseljencev po manjših prostorskih popisnih okoliših. Občine z najvišjim indeksom segregacije (Recoleta, Independencia in Estación Central) so poleg prej omenjenih sečiščnih občin tudi tiste, ki v nekaterih popisnih okoliših ob središčni občini Santiago dosegajo zelo visok delež perujskih priseljencev. Najmanjši indeks segregacije ima občina Providencia, ker deleži perujskih priseljencev skoraj v vseh obravnavanih statističnih enotah pripadajo isti skupini, od 0,59 do 1,43\%. Indeks segregacije središčne občine Santiago ni tako visok, 0,34 , saj so višji deleži perujskih priseljencev v popisnih okoliših središčne občine razmeroma enakomerno porazdeljeni.

Ker priseljenci pogosto živijo v slabših bivanjskih razmerah, smo preučili tudi prezasedenost stanovanj po popisnih okoliših in deleže perujskih priseljencev v centralnih občinah po spolu. Kazalnik prezasedenosti stanovanj (hacinamiento) seže od 0 do 100 . V gospodinjstvu je stanovanje prezasedeno, če mora v eni sobi spati več kot 2,5 osebe. Več gospodinjstev nakaže prezasedenost stanovanj, višji je odstotni delež v popisnih okoliših. V obravnavanem raziskovalnem območju centralnih občin sežejo deleži prezasedenosti stanovanj od 0,07 do $20 \%$. Na prvi pogled vidimo, da so višje vrednosti večinoma zastopane v obrobnih popisnih okoliših (slika 3).

Tretji kartogram (slika 3) predstavlja življenjski standard prebivalcev po popisnih okoliših centralnih občin. Izračunali smo ga z indeksom socialnoekonomskega razvoja (Borsdorf in Hidalgo 2004). Indeks sestavljajo trije deli. Prvi del izračunamo s pomočjo luksuznega blaga, kot so avto, hladilnik, televizija, internet, pralni stroj. V drugem delu primerjamo stopnjo izobrazbe prebivalstva po popisnih okoliših, tretji del pa določajo tri spremenljivke kakovosti bivališča (streha, dno in stena). Razpon indeksa seže od 0 do 1 , pri čem 0 pomeni zelo slabo in 1 zelo dobro kakovost življenja. Razporejenost kakovosti življenja kaže zelo podobno sliko, kot kartogram prezasedenosti stanovanj. To seveda ni presenetljivo, ker se lahko domneva, da je višja prezasedenost stanovanj v območjih z nižjim življenjskim standardom. Slika 3 nam zelo lepo pokaže povezanost teh dveh kazalnikov. Prezasedenost stanovanj je proti vzhodu, v občinah Providencia in Nunoa, zelo nizka, kakovost življenja pa razmeroma visoka. $V$ teh dveh občinah prevladuje ženski delež perujskih priseljencev.

Ob primerjavi razporejenosti perujskih priseljencev s prezasedenostjo stanovanj ali z življenjskim standar dom prebivalcev pomembnejše povezave na prvi pogled niso razvidne. Višji deleži perujskih priseljencev so v centru, višji deleži prezasedenosti stanovanj in slabšega življenjskega standarda pa izven centra. Ob podrobnejši primerjavi popisnih okolišev z višjimi deleži perujskih priseljencev, zlasti v sečiščnih občinah Santiago, Independencia in Recoleta, lahko zaznamo povezanost med višjo prezasedenostjo stanovanj, slabšim življenjskim standardom in višjim številom perujskih priseljencev. Obstajajo pa tudi posamezni popisni okoliši z visokim številom perujskih priseljencev, boljšim življenjskim standardom in nizko prezasedenostjo stanovanj. Omenjena povezanost slabšega življenjskega standarda z višjim delom perujskih priseljencev v območju sečiščnih občin torej izkazuje tendenco povezanosti med kazalnikoma.

Od 12 središčnih občin Santiaga ima občina Santiago največje število perujskih priseljencev. Leta 2002 je v občini Santiago živelo 4099 Perujcev - 41 \% vseh perujskih priseljencev središčnih občin. Zaradi tega smo kot tretjo raven raziskave določili centralno občino Santiago. V njej je tudi staro mestno jedro, ki ga je od leta 1995 naprej priseljevanje Perujcev najbolj zaznamovalo. 
V popisnem okolišu, kjer je glavi mestni trg Santiaga Plaza de Armas, je delež perujskih priseljencev $4,01 \%$. Razmeroma visok delež perujskih priseljencev se kaže tudi navzven, zlasti na območju glavnega trga in njegove ožje okolice.

Središče dogajanja je v severozahodnem kotu trga, ki je za številne perujske priseljence prvo mesto, kjer lahko navežejo prve stike $\mathrm{z}$ rojaki. Večina Perujcev, ki se tam združuje, je brezposelnih in čakajo tam na morebitno priložnost za delo. Nekateri avtorji imenujejo okolico glavnega trga la Lima chica - majhna Lima (Luque Brazan 2007, Stefoni 2007b).

$\mathrm{Na}$ istem koncu glavnega trga je tudi največ perujskih trgovin in pisarn. Večinoma so to klicni centri, ki ponujajo poceni klice, zlasti v Peru. Številne napisi in reklame pocenih clicev v Peru nakaže, da je klientela večinoma iz peruja. $V$ isti ulici sta tudi menjalnica in izpostava za prenos denarja, ki se imenuje Peru Courier Service. V bližini sta še perujska restavracija in perujska trgovina z živili. Na prisotnost Perujcev kažejo tudi reklamni napisi. Prvi dela reklamo za perujski radijski spored z imenom tardes peruanas - perujski večeri, oddajo, ki je na sporedu od ponedeljka do petka. Druga reklamna plošča oglašuje različne trgovine podzemne pasaže, med drugim tudi perujsko trgovino.

Na obravnavanem območju raziskave smo našli tri perujske restavracije in dve trgovini s perujsko umetno obrtjo. Čeprav je delež Perujcev na celotno prebivalstvo razmeroma majhen, je njihova prisotnost sodeč po navedenih perujskih ustanovah zelo očitna in vse bolj daje podobo posameznim mestnim ulicam.

Ena od očitnejših ugotovitev naših raziskav je tudi, da so območja, kjer zasledimo višji delež peruj skih priseljenk (zlasti severovzhod), praviloma območja z višjim življenjskim standardom (glej sliki 2 in 3 ). Zato smo v tretji ravni raziskave podrobneje preučili občino Las Condes, ki leži na severovzhodu mesta in predstavlja zelo dober primer občine s prebivalstvom višjega socialnega sloja.

Slika 5: Delež perujskih priseljencev, ženski deleži, občina Las Condes 2002.

Glej angleški del prispevka.

Las Condes sodi skupaj z na severu ležečima sosednjima občinama Vitacura in Lo Barnechea ter z za hodno ležečo sosednjo občino Providencia med najbogatejše občine Santiaga, Leta 1996 je več kot polovica najbogatejših prebivalcev Santiaga živela v občinah Providencia, Las Condes in Vitacura. To kaže na razvoj socialne neenakosti in polarizacijo metropolitanskega območja Santiaga, kar je že dlje časa interesno področje različnih znanstvenikov (Borsdorf, Bähr in Janoschka 2002).

V občini Las Condes je povprečni delež žensk perujskih priseljencev zelo visok (82\%). V primerjavi z središčnim občinam metropolitanska območja Santiaga so deleži perujskih priseljencev v občini Las Condes bolj nizki. Višja koncentracija perujskih priseljencev na severu občine dosežejo 2,7 \% nad celotnim prebivalstvom statističnih enot. Na jugu občine je delež Perujcev manj (od 0,58 do 0,80\%). Struktura priseljencev v občini kaže visoko prevlado priseljenk, ponekod je delež žensk kar $97 \%$. V ostalih popisnih okoliših proti jugu in zahodu so ženski deleži tudi še zelo veliki, od 61,01 do 82\%. Samo štiri, površin sko zelo majhni popisni okoliši nakažejo manjši deleži perujskih žensk, od 50 do $61 \%$ (glej slika 5).

$\mathrm{V}$ aktualnem poglavju po ravnih obravnavana prostorska porazdelitev perujskih priseljencev poka že zelo zanimive slike. Hkrati se pa nam ustavijo še odprta vprašanja, kot je to vprašanje za prevladujoči delež perujskih žensk v severozahodnih, bogatejših občinah Santiaga.

Sodobni avtorji (Martinez 2003; Huatay 2005; Stefoni 2007b) označujejo novo perujsko imigracijo po letu 1995 kot delovno migracijo nižjega socialnega sloja. To izjavo smo želeli preveriti v naslednjem poglavju 4. Struktura prebivalstva perujskih priseljencev v Santiagu nam bo tudi razložila tendenčno prostorsko prevlado žensk na severozahodu metropolitanskega območja Santiaga.

\section{Struktura perujskih priseljencev v Santiago (Čile)}

Z raziskavo strukture perujskih priseljencev želimo odgovoriti na nekatera odprta vprašanja iz raziskave prostorske porazdelitve, nadejamo pa si tudi ugotovitve o vzrokih in vrsti migracije. $\mathrm{V}$ tem smislu smo si zastavili nekaj vprašanj:

- Zakaj so perujski priseljenci ravno tako razporejeni v prostoru?

- Zakaj prevladuje ženski delež na severovzhodu urbanega območja Santiaga?

- S čim se ukvarjajo, kakšne so dejavnosti perujskih priseljencev? 
- Katere starostne skupine so najbolj zastopane?

- Ali obstajajo informacije o socialnim statusu perujskih priseljencev? ...

Pri raziskavi strukture priseljencev smo zopet delali s podatki zadnjega popisa prebivalstva iz leta 2002. Rezultate smo primerjali med ravnmi, omenjenimi že v uvodu: metropolitansko območje Santiaga (raven 1) in občine Santiago in Las Condes (raven 3). V članku bomo omenili samo tiste primerjave, pri katerih smo ugotovili pomembne razlike oziroma našli odgovore na naša vprašanja. $V$ ta namen bomo predstavili demografsko strukturo, in sicer s kazalniki starostne, zaposlitvene, socialne in spolne strukture.

Slika 6: Starostna spolna sestava perujskih priseljencev, metropolitansko območje Santiaga 2002 (vir: INE Chile, Censo 2002). Glej angleški del prispevka.

Starostna piramida perujskih priseljencev metropolitanskega območja Santiaga pokaže, da je večina perujskih priseljencev v starostnih skupinah med 20 in 40 let (sliko 6). Delež otrok in starejših je zelo majhen. Najmanjši deleži pripadajo skupinam med 0 in 4 leta ter starostnim skupinam od 60 let navzgor. Piramida nam pokaže, da so skoraj vsi perujski priseljenci v Santiagu v skupinah, ki predstavljajo delovni kontingent. S tem lahko potrdimo tezo o delovni migraciji perujskih priseljencev v Santiagu. Starostna piramida nam pokaže tudi na višji delež žensk. Največji delež predstavljajo mlade perujske priseljenke, stare od 25 do 29 let.

Slika 7: Razdelitev perujskih priseljencev po položaju v poklicu, metropolitansko območje Santiaga 2002 (vir: INE Chile, Censo 2002). Glej angleški del prispevka.

Zaposlitvena kvota delovno aktivnega prebivalstva perujskih priseljencev metropolitanskega območja Santiaga znaša 76,22 \%, kvota brezposelnih perujskih priseljencev pa 7,30 \%. V središčni občini Santiago je zaposlitvena kvota malo nižja $72,07 \%$ in kvota brezposelnosti višja $11,22 \%$. V občini Las Condes je zaposlitvena kvota veliko višja in znaša 88,84 \%, kvota brezposelnosti je zelo nizka in znaša samo 1,98 \%.

Zaposlitveno strukturo perujskih priseljencev smo primerjali prek položaja v poklicu. Na metropolitanskem območju Santiaga smo ugotovili dve težišči (glej sliko 7). Prvo težišče $46 \%$ predstavlja skupina delavcev in drugo 44,71 \% skupina hišnih pomočnic in pomočnikov. Obe skupini zajemata $90,73 \%$ vseh perujskih priseljencev metropolitanskega območja. Ostali delajo v samostojnem poklicu (6,84\%), kot delodajalci ali podjetniki $(2,10 \%)$ in samo $0,33 \%$ je svojcev brez poklica.

Ob primerjavi občine Santiago in Las Condes vidimo zelo zanimive razlike. V središčni občini Santiago predstavlja težišče nedvomno skupina delavcev (60,86 \%). Druga skupina so hišne pomočnice in hišni pomočniki $(27,47 \%)$. V občini Las Condes, kjer ženski delež perujskih priseljencev močno prevladuje, je ravno obratno. Prvo težišče predstavljajo hišne pomočnice $(77,10 \%)$. Skupina delavcev je v občini Las Condes razmeroma majhna $(18,19 \%)$.

Slika 8: Najvišja stopnja izobrazbe perujski priseljencev, metropolitansko območje Santiaga 2002 (vir: INE Chile, Censo 2002). Glej angleški del prispevka.

Socialno strukturo perujskih priseljencev smo opredelili s kazalnikoma najvišje stopnje izobrazbe in bivanjskih tipov perujskih priseljencev. Raziskava dohodkovne strukture ni bila možna, ker ni primernih podatkov. Socialno strukturo lahko preučimo tudi s prej omenjeno zaposlitveno strukturo.

Čez 80 \% perujskih priseljencev metropolitanskega območja Santiaga ima končano srednjo ali strokovno šolo in univerzo (glej sliko 8). Stopnja izobrazbe perujskih priseljencev je tako razmeroma visoka. $14,14 \%$ perujskih moških in $16,18 \%$ perujskih žensk ima nižjo stopnjo izobrazbe (mala šola in osnovna šola). Samo 0,18 perujskih moških in 0,58 perujskih žensk nima nobene izobrazbe. Večja razlika med spo loma je le pri univerzitetni izobrazbi, kjer prevladujejo perujski moški.

Primerjava stopnje izobrazbe med občinami Santiago in Las Condes pokaže boljšo izobrazbeno strukturo v občini Las Condes, kjer je več perujskih priseljencev zaključilo univerzitetno izobrazbo.

Slika 9: Bivanjski tipi perujskih priseljencev, metropolitansko območje Santiaga 2002 (vir: INE Chile, Censo 2002).

Glej angleški del prispevka. 
Pri bivanjskih tipih so priseljenci razdeljeni na 6 kategorij (glej sliko 9). Večina jih živi v hiši $(62,27 \%$ ), sledijo tisti, ki živijo v stanovanju (20,61\%). Tretja skupina priseljencev živi v kategoriji conventillo- samostanček $(12,24)$. Conventillo - samostanček se imenuje kategorija enosobnih stanovanj znotraj kvadratnih blokov v starem mestnem jedru Santiaga. Sobe so razporejene vzdolž skupnega hodnika, kjer je tudi skupno stranišče. Convetillo je stara oblika bivanja, v prvi vrsti za nižji socialni sloj. V Santiagu so bili convetillos prvi cilj priseljencev že v času migracij prebivalstva iz podeželja v mesto (Borsdorf, Bähr in Janoschka 2002).

Primerjava med središčno občino Santiago in severovzhodno ležečo občino Las Condes pokaže važno razliko. Bivanjski tip conventillo je v občini Santiago zelo visok $(31,81 \%)$, v občini Las Condes pa sploh ne obstaja. Tam živi večina perujskih priseljencev v hiši (60,74\%), ostali pa v stanovanju. Že prej smo izvedli, da v občini Las Condes živijo večinoma perujske ženske, ki večinoma delajo kot služkinje. Visoki deleži priseljencev, živečih v hiši ali stanovanju nam pokaže, da perujske služkinje tudi živijo v hišah tujih družin.

Slika 10: Glavna področja zaposlitve perujkih žensk, metropolitansko območje Santiaga 2002 (vir: INE Chile, Censo 2002). Glej angleški del prispevka.

Slika 11: Glavna področja zaposlitve perujski moških, metropolitansko območje Santiaga 2002 (vir: INE Chile, Censo 2002). Glej angleški del prispevka.

V članku smo spolno strukturo perujskih priseljencev že prikazali (poglavje 3). 61 \% perujskih pri seljencev metropolitanskega območja so ženske. Sliki 10 in 11 nam pokažejo glavna področja zaposlitve perujskih priseljencev po spolu. Od več kot 90 različnih oblik zaposlitve smo izpostavili samo najvažnejših šest. Takoj lahko opazimo, da so perujske ženske zaposlene predvsem kot hišne pomočnice (75,58\%). V nasprotju z njimi so perujski moški bolj razdeljeni po različnih oblikah zaposlitve. Nakazali smo le glavna področja, kjer je zaposlenih več kot $4 \%$ perujskih priseljencev. To so trgovina na drobno, gradbeništvo, podjetniške dejavnosti, hoteli in restavracije, prevozništvo in pomoč na domu (hišni pomočniki).

\section{Sklep}

Prostorska razporejenost in demografska sestava perujskih priseljencev Santiaga je zelo zanimiva, in v slovenski geografski literaturi še ni bila predstavljena (Zorn in Komac 2009). Največ perujskih priseljencev živi v centralnih popisnih okoliših Santiaga. Njihovo navzočnost kažejo številne perujske trgovine, zlasti v okolici glavnega trga Plaza de Armas. Izpostave za prenos denarja ter klicni centri so tudi znaki transnacionalizma, ko priseljenci vzdržujejo stike z domovino. Prevladuje delovna migracija, ki smo jo dokazali s starostno piramido in zelo visokim deležem zaposlenosti. Večina perujskih priseljencev je stara med 20 in 40 let. Perujskih otrok in starejših priseljencev nad 60 let je zelo malo. Ugotovili smo tudi, da je več žensk kot moških in da večinoma delajo kot hišne pomočnice pri družinah, kjer tudi živijo. Delež perujskih žensk je visok zlasti v bogatejših občinah na severozahodu Santiaga. Kartografska primerjava središčnih občin nam je tudi pokazala tendenčno povezanost med višjim deležom perujskih priseljencev, prezasedenost jo stanovanj ter slabšo kakovostjo življenja. V analizi socialne strukture smo ugotovili razmeroma visoko stopnjo izobrazbe perujskih priseljencev, predvsem bogatejših občinah. Najvažnejši bivanjski tipi priseljencev so hiša, stanovanje in v starem mestnem jedru enosobna stanovanja conventillo - samostanček. Socialni status perujskih priseljencev je težko določljiv. Enosobna stanovanja (conventillo) v starem mest nem jedru Santiaga pripadajo večinoma nižjemu socialnemu sloju. Zlasti v bogatejših delih je očitna povezava med poklicem in tipom bivanja. Perujski priseljenci namreč živijo in delajo v hišah ali stanovanjih tujih družin, kar je ponovno znak nižjega socialnega statusa. Nasprotno stanje kaže stopnja izobrazbe, ki je raz meroma visoka. $V$ prispevku smo obravnavali razporeditev in strukturo perujskih priseljencev v Santiagu. Prišli smo do številnih zanimivih ugotovitev, ki pa so nemalokrat omejene z razpoložljivimi podatki. Obrav navali smo namreč le registrirane priseljence, zagotovo pa je več takih, ki svojega statusa še nimajo urejenega. Zato bodo kljub našemu trudu številna vprašanja ostala še v naprej neodgovorjena.

\section{Literatura}

Glej angleški del prispevka. 